Author-produced version of the article published in Trends in Food Science and Technology, 2009,20 (8), $333-343$.

Original publication available at www.sciencedirect.com - doi:10.1016/j.tifs.2009.04.001

\title{
Crust formation and its role during bread baking
}

Vanin, F.M. ${ }^{1,2}$; Lucas, T. ${ }^{1,2}$; Trystram, G. ${ }^{3}$

$3 \quad{ }^{1}$ CEMAGREF, Food Process Engineering Research Unit, RENNES

4 (France)

$5 \quad$ 2Université Européenne de Bretagne, F-35000 Rennes, France

$6 \quad{ }^{3}$ AgroParisTech, Joint Research Unit Food Process Engineering MASSY

7 (France)

8

9 The final properties of the crumb and crust differ according to their heat-

10 moisture dynamics. Compilations of heating and drying rates reported in

11 the literature are discussed and will serve to validate future models of

12 baking. Their impact on the structural elements in dough films and the

13 porous network are discussed, highlighting the lack of data and the need to

14 reproduce these dynamics inside the instrument of analysis. Some roles of

15 the crust setting during the whole baking process are also presented,

16 suggesting further research in this area. Finally, as the region covered by

17 the crust should be defined as a starting point to future studies, definitions

18 proposed in the literature are discussed.

\section{Keywords}

20 crust, bread, baking, water loss, temperature, heating rate, heat and mass

21 transfer, mathematical model, porosity, permeability, rheology, starch

22 gelatinization, oven-rise, density, bubble, cell, $\mathrm{CO}_{2}$ release, pressure

23 *Corresponding author. Tel: + 33 (0)2 234821 77; fax: +33 (0)2 2348

242115.

25 E-mail address: tiphaine.lucas@cemagref.fr 


\section{$1 \quad 1 \quad$ Introduction}

2 During baking, heat (HT) and moisture (MT) transport take place in the

3 dough simultaneously and interdependently, and involve three major

4 changes - (for further details see recent review by Mondal \& Datta (2007)):

5 (1) Water vaporises at the cell/dough interface, and gases accumulated

6 during fermentation $\left(\mathrm{CO}_{2}\right.$, ethanol) or generated by chemical raising agents

7 are also vaporised: the cell volume increases provided that the dough film

8 retains gases and is deformable.

9 (2) Starch gelatinisation and protein coagulation transform the viscous

10 dough into a mainly elastic crumb; these rheological changes limit the cell

11 growth described in (1) and enhance pressure build-up.

12 (3) The structure with gas cells separated by films is transformed into a

13 porous structure with inter-connected pores. In theory ruptured films limit

14 cell growth (1): gas molecules are exchanged between adjacent open cells,

15 and finally transported out of the dough. Dough films rupture when they

16 can no longer withstand over pressure. Film rupture is often associated with

17 the onset temperature of starch gelatinisation (Bloksma, 1990) or a higher

18 temperature. This is also likely to happen if pressure is low, but the dough

19 film presents poor mechanical resistance, as when the protein content in the

20 flour is low, the water content in dough is high, or if the dough is under or

21 over-kneaded (Dobraszczyk \& Salmanowicz, 2008).

22 The crust and crumb come from the same original dough, but their final

23 properties differ according to a distinct local heat-moisture treatment. As

24 soon as the dough is placed in the oven, water evaporates very fast from the

25 surface layers, resulting in a much lower water content $(<20 \%$ wet basis $)$ 
1 than at the core. The total water loss (WL) from the crust is obviously of

2 economic significance (weight loss). Water distribution between the crust

3 and crumb also contributes substantially to the organoleptic perception of

4 the final product. As the water activity (Aw) of sponge cake increased from

$5 \sim 0$ to 0.75 , both initial modulus and critical stress fell by an order of

6 magnitude with both correlating $(r>0.90)$ with a trained panel's assessment

7 of sensory harness (Attenburrow, Goodband, Taylor \& Lillford, 1989). A

8 crispy texture is also associated with low moisture content and water

9 activity, when starch and gluten matrix are in a glassy state making cells

10 walls more prone to fracture (Stokes \& Donald, 2000). Low water content

11 in the crust will also affect the rheological changes in the dough films and

12 ultimately the cell growth during baking. Starch gelatinisation and protein

13 denaturation are limited when there is restricted access to water. This has

14 an effect antagonistic to the one of the decreasing water content and may

15 prolong the deformability of dough films. The enhanced escape of gases

16 due to the proximity of the boundary to the oven may explain the smaller-

17 sized cells which are typical of the crust. These obviously contribute to the

18 mechanical properties of the crust (resistance to rupture during baking,

19 texture in mouth) in addition to the low water content.

20 As the water content decreases in the crust, the temperature can exceed $21100^{\circ} \mathrm{C}$, which supports other reactions such as the Maillard reaction 22 responsible for the development of colour and the release of flavours, and 23 also the production of toxic compounds with safety implications (Ahrne, 24 Andersson, Floberg, Rosen \& Lingnert, 2007). 
1 Reactions specific to the crust also jeopardize the nutritional value of the

2 baking process. On the one hand, the Maillard reaction decreases the

3 protein digestibility and the lysine bioavailability of lysine which is the

4 limiting amino-acid in cereal products (O'Brien \& Morrissey, 1989). On the

5 other hand, gelatinised starch can be degraded by amylases from the saliva

6 whereas ungelatinised fraction undergoes a much slower metabolism and

7 can remain undigested. Conversely, health benefits (obesity risk reduction)

8 are claimed since bread rolls with a higher proportion of crust have been

9 reported to raise capillary blood glucose more slowly than a corresponding

10 loaf (Glatzel \& Rettenmaier, 1962).

11 All these microstructural changes in the cell size and dough films also

12 contribute to the structural differentiation of the crust. Most previous

13 studies have focused on the crust properties at the end of baking or their

14 changes during storage (Luyten, Pluter \& van Vliet, 2004), but the setting

15 of these properties during the baking and post-chilling processes have been

16 little studied to date.

17 The first aim of this review is therefore to present how the well known final

18 properties (once cooled) are created dynamically during baking and how

19 the underlying transformations differ from those in the crumb (section 2).

20 The crust properties differ from a bread making technology to another (pan

21 bread versus hearth bread for instance), but also from one face to the other,

22 depending on the extent of heat and mass transfer at the bottom and top

23 surfaces for instance. Given the very few data available in the literature on

24 the topic, elaborating a typology from this review is out of scope; however, 
1 the variety present in the literature will help to identify key factors in the

2 crust setting process.

3 Improvements in the observation techniques will be highlighted in section 2

4 and summed up in the conclusion.

5 As the crust cannot be considered separately from the rest of the bread, but

6 interacts with other mechanisms, some of its role during baking already

7 identified in the literature will be presented in section 3 .

8 As changes in bread are gradual, proposing a simple definition of the crust

9 is a difficult although necessary starting point for future studies, a second

10 focus of the concluding section (4).

11

122 Mechanisms specific to the bread surface and contributions to

13 crust formation

\section{$14 \quad 2.1 \quad$ Temperature}

15 Surface temperature quickly reaches $100^{\circ} \mathrm{C}$ and then approaches more

16 slowly the oven air temperature. This rapid increase in surface temperature

17 is enhanced i) by the low thermal conductivity of the aerated dough limits

18 HT at core; ii) by high radiation originating from the warm oven walls

19 (from 66.2 to $81.5 \%$ of overall HT) (Baik, Marcotte \& Castaigne, 2000).

20 Surface temperatures exceeding $100^{\circ} \mathrm{C}$ are explained by the difference in

21 water content between surface and core: water evaporates from the surfaces

22 more quickly than it can be transported from the core; in addition, due to

23 the evaporation-condensation-diffusion mechanism (Wagner, Lucas, Le

24 Ray \& Trystram, 2007), water content remains almost constant at the core. 
1 Table 1 summarizes the heating rates observed at the surface compared to

2 the centre, as approximated by the slope of the linear segment between the

3 initial temperature and $100^{\circ} \mathrm{C}$. The heating rate was high in the crust (up to

$4 \quad 14.4^{\circ} \mathrm{C} / \mathrm{min}$ ) while not exceeding $3^{\circ} \mathrm{C} / \mathrm{min}$ at core. Note that time derivation

5 of temperature kinetics gave even higher values $\left(20\right.$ to $\left.35^{\circ} \mathrm{C} / \mathrm{min}\right)$ at the

6 onset of baking.

7 Temperature was measured using thermocouples (Zanoni \& Peri, 1993;

8 Dogan, 2002; Lostie, Peczalski, Andrieu \& Laurent, 2002a) or optic fibres

9 (Wagner, Loubat, Sommier, Le Ray, Collewet, Broyart et al., 2008b)

10 placed at different locations inside the loaf, usually only near the top

11 surface and in the centre. However, this intrusive technique introduces

12 biases, including delicate positioning (1-3mm of accuracy), possible heat

13 conduction along the metallic wire of the thermocouple and constraint to

14 oven-rise. To minimize such bias, surface temperature can be monitored by

15 infra-red sensors (Lostie, Peczalski, Andrieu \& Laurent, 2002b; Primo-

16 Martin, van Nieuwenhuijzen, Hamer \& van Vliet, 2007).

\section{$17 \quad 2.2$ Water content}

18 The water content in the crumb remains almost constant compared to the

19 initial value while considerable dehydration occurs in the crust (

20 Figure 1). Water activity can also be used to describe the result of WL and

21 its effects on water availability, reaction kinetics and mechanical properties

22 (Czuchajowska, Pomeranz \& Jeffers, 1989; Lind \& Rask, 1991; Bassal,

23 Vasseur \& Lebert, 1993; Dogan, 2002; Van Nieuwenhuijzen, Tromp,

24 Hamer \& Van Vliet, 2007). Given the low final water content in the crust ( 
1 Figure 1), a moderate variation in water content can affect Aw considerably

2 (Lind et al., 1991). Aw is also involved in the calculation of water transfer

3 during baking, since the driving force was generally assumed to be the

4 difference in partial vapour pressure between the product surface and the

5 oven atmosphere. Aw was measured at ambient temperatures, and very

6 little information is available for temperatures observed in the crust during

7 baking. Studies have been carried out at $100-150^{\circ} \mathrm{C}$ for cake dough (Bassal

8 et al., 1993), and at $80-120^{\circ} \mathrm{C}$ for wet and dried crumb (Jury, Monteau,

9 Comiti \& Le-Bail, 2007). Additionally, the assumption of thermodynamic

10 equilibrium between liquid and gaseous phases on which the measurement

11 of Aw is based have also been questioned, given the high heating rates

12 involved during baking (Zhang \& Datta, 2006). This approach was

13 therefore not included in this review.

14 HT has been considered the main driving force for water vaporisation; in

15 other words, MT from the vaporisation front to the loaf outside, proceeding

16 mainly by convection, was not considered to be a limiting factor (Lostie,

17 Peczalski \& Andrieu, 2004; Zhang, Doursat, Flick \& Lucas, 2008). HT can

18 be enhanced by increasing the oven air temperature, and eventually the air

19 renewal at the product surface; these variables have consistently been

20 experimentally correlated to WL (Wahlby \& Skjoldebrand, 2002). The

21 addition of steam increased the relative humidity of the oven air to $0.7-0.9$

22 (Wiggins, 1998). As the dough surface was cold compared to the

23 surrounding air, moisture condensed onto it from the air, up to $1 \%$ of loaf

24 weight. Steam injection thus reduced WL at the onset of baking. However,

25 as the surface reached the dew point temperature, steam accelerated 
1 temperature rise and WL for long baking times (Eliasson \& Larsson, 1993).

2 Chevallier, Della Valle, Colonna, Broyart \& Trystram (2002) reported

3 greater WL with higher air humidity in the oven (20 to $400 \mathrm{~g} / \mathrm{kg}$ of dry air)

4 for biscuits. Internal resistance to HT also affects WL; because this

5 involves interlinked mechanisms, it will be discussed in section 3.

6 Water content was generally obtained by weighing the product after

7 stopping the baking process at different times, which is extremely time

8 consuming. Moreover, assessing profiles requires cutting the loaf into

9 samples while still hot, and also deformable. Vaporisation of water from

10 cut surfaces and squeezing crumb samples are thus sources of bias. Another

11 difficulty of the sampling method was separating the crust from the crumb.

12 Thorvaldsson \& Skjöldebrand (1996) developed an infrared method for

13 continuous measurement of local water content, but the effect of crumb

14 density on the infrared signal was not corrected, generating bias during the

15 oven rise period.

16 Validating the thorough description of the mechanisms of water transport

17 (Zanoni et al., 1993; Lostie et al., 2002a; Lucas, Wagner, Doursat, Flick \&

18 Trystram, 2009) would obviously require higher spatial and temporal

19 resolution for profiles of water content; this difficulty has been

20 demonstrated for the crumb (Lucas et al., 2009) and is valid for the crust

21 with even greater acquisition constraints (spatial domain of a few hundred

22 to a few thousand $\mu \mathrm{m}$ ). Note that experimental evidence hardly supports a

23 modelling approach based on uniform temperature and water content as

24 suggested by (Fan, Mitchell \& Blanshard, 1999). 


\section{$1 \quad 2.3 \quad$ Biochemical reactions}

\subsubsection{Starch gelatinisation}

3 The degree of starch gelatinisation (DSG) can be observed on final cereal

4 products (once completely cooled) by the loss of birefringence of starch

5 granules or the disappearance of the "Maltese crosses" observed in

6 polarized light (Eliasson et al., 1993; Jenkins \& Donald, 1998). DSG has

7 been shown to be directly affected by water (Burt \& Russell, 1983; Le

8 Meste, Huang, Panama, Anderson \& Lentz, 1992; Jenkins et al., 1998;

9 Fessas \& Schiraldi, 2000; Cuq, Abecassis \& Guilbert, 2003) and the

10 heating rate (Donovan, 1979; Bloksma, 1980), which again both differ

11 between the crust and crumb. If DSG consistently differed between cereal

12 products because of their different compositions and baking times (Eliasson

13 et al., 1993), it also varied within the same product: the greater the distance

14 to the surface, the greater the starch gelatinisation (Luyten et al., 2004). Up

15 to $40 \%$ of the starch in the crust did not gelatinize during bread baking

16 (Primo-Martin et al., 2007). This was consistent with DSC measurements

17 carried out with open pans (Fessas et al., 2000): for a global water content

18 decreasing from 44.2 to $30.7 \%$ (wb), DSG was about $44 \%$-instead of $66 \%$

19 measured for sealed pans at initial water content of $44.2 \%$.

20 Heat-moisture treatment of starch is known to affect the gelatinisation

21 temperature. Differential scanning calorimeter (DSC) thermograms

22 obtained from samples of high water content ( $>90 \%$ wet basis (wb))

23 exhibited a single endotherm peak (

24 Figure 2). Beyond this point and at water contents above $\sim 60 \% \mathrm{wb}$, the 25 endotherm presented three major endotherms (Eliasson, 1980; Burt et al., 
1 1983; Champenois, Colonna, Buléon, Valle \& Renault, 1995), the first

2 peak corresponding to cooperative, water-mediated melting of starch

3 crystallites, the second peak to the melting of the remaining crystallites, and

4 the third to amylose-lipid complex melting transition (Biliaderis, Maurice

5 \& Vose, 1980; Burt et al., 1983; Chevallier, Colonna \& Lourdin, 2000;

6 Fessas et al., 2000). As water content progressively decreased below this

7 point, the intensity of the first endotherm was reduced, but remained at

8 almost the same temperature (

9 Figure 2), until its total disappearance below to $35 \%$ of water (Eliasson,

10 1980; Burt et al., 1983; Champenois et al., 1995). Conversely, Sopade,

11 Halley \& Junming (2004) reported an increase in the gelatinisation

12 temperature of $1.1^{\circ} \mathrm{C}$ for a reduction in water content from 50 to $40 \% \mathrm{wb}$.

13 At the same time, when water content was lower than $60 \%$ the second and

14 third endotherms moved to higher temperatures but at different rates (

15 Figure 2) and finally merged into a single endotherm above 35\%wb (Burt

16 et al., 1983; Champenois et al., 1995). In fact, the starch granules and the

17 gluten will compete for water, which will result in an additional increase in

18 the gelatinisation temperature (Eliasson et al., 1993; Wang, Choi \& Kerr,

19 2004). The loss of birefringence observed for very low water content

$20(<25 \%)$ and at high temperatures was related to the second endotherm (Burt

21 et al., 1983). A peak at $70^{\circ} \mathrm{C}$ was observed in the thermogram of a freshly

22 sampled crust, corresponding to the starch crystals that did not gelatinise

23 during baking, in addition to the peak corresponding to the amylose-lipid

24 complex (Primo-Martin et al., 2007). 
1 Some studies have also shown that the gelatinisation temperature was

2 affected by the heating rate. Although applicable to potato starch,

3 (Donovan, 1979) observed that the greater the heating rate $\left(2\right.$ to $\left.10^{\circ} \mathrm{C} / \mathrm{min}\right)$,

4 the higher the temperature of the endotherm peak $\left(+2^{\circ} \mathrm{C}\right)$. Likewise, Patel

5 \& Seetharaman (2006) observed a shift in the swelling of wheat starch

6 granules at higher temperatures when the heating rate increased from 5 to

$725^{\circ} \mathrm{C} / \mathrm{min}$. It must be mentioned here that changes in dough viscosity were

8 also delayed by increasing the heating rate from 3 to $9^{\circ} \mathrm{C} / \mathrm{min}$ (Bloksma,

9 1980).

10 To conclude, it can be expected that starch granules present in the

11 superficial layers only partially gelatinise, because of the strong reduction

12 in water content and the more rapid heating rates, which both increase the

13 starch melting temperature. This will influence the rheological properties of

14 dough films during baking and possibly cell growth in the crust. As far as

15 the crust is concerned, it would be interesting to characterise this reaction

16 during simultaneous heating and drying.

$17 \quad 2.3 .2 \quad$ Gluten coagulation

18 The lower the water content, the higher the denaturation temperature of

19 proteins (Eliasson et al., 1993). For $\omega$-gliadin aqueous solutions for

20 instance, it increased from 117 to $157^{\circ} \mathrm{C}$ by lowering the water content

21 from 20 to 3\%wb (Noel, Parker, Ring \& Tatham, 1995). Denaturation is

22 followed by aggregation and, for some proteins, gel formation (Eliasson et

23 al., 1993). In contrast to the first stage, this stage is a kinetics-dependent

24 exothermic process: the lower the heating rate, the more advanced the 25 process of aggregation (Myers, 1990). 
1 As a consequence of these combined effects, the bread crust showed a

2 minimal decrease in water-extractible proteins, meaning that they were not

3 as aggregated and/or cross-linked as in the crumb (Westerlund, Theander \&

4 Aman, 1989). This would undoubtedly affect the mechanical modifications

5 of the gluten network in the superficial layers upon heating. The

6 disappearance of soluble protein was almost complete in wheat gluten and

7 glutenin at $25-30 \% \mathrm{wb}$ of water content heated at very high rates $\left(25^{\circ} \mathrm{C} / \mathrm{s}\right.$

8 from 40 to $170^{\circ} \mathrm{C}$ ) (Strecker, Cavalieri, Zollars \& Pomeranz, 1995); to the

9 light of this last study, results from Westerlund et al. (1989) could be

10 explained to the very low water content encountered in bread crust.

11 The amount of water to be released was also expected to be lower, with

12 possible limitations on other biochemical reactions including starch

13 gelatinisation (Marston \& Wannan, 1976; Wang et al., 2004) and/or to

14 water transport (Thorvaldsson \& Skjöldebrand, 1998; Mondal \& Datta, 15 2008).

16 Glass transition (GT) is also an issue given the low water contents 17 associated with high temperatures (Huang, Haynes, Levine \& Slade, 1996) $18 \quad($

19 Figure 2). However, it is commonly accepted that GT usually occurs upon 20 cooling (Cuq et al., 2003) -also see

21 Figure 2, which is outside the scope of this review and is not discussed 22 here. Nevertheless local heat-moisture treatment during baking (sections 232.1 and 2.2) undoubtedly affect the consecutive process of GT during post24 chilling. 
2 Highly reactive compounds are initially produced from this reaction;

3 afterwards, their polymerization yields products of brown colour (Martins,

4 Jongen \& van Boekel, 2001) observable at around $105-115^{\circ} \mathrm{C}$ (Zanoni, Peri

5 \& Bruno, 1995a; Broyart, Trystram \& Duquenoy, 1998; Wahlby et al.,

6 2002). Starch is also consumed during the reaction, leading to a reduction

7 in the starch concentration in the crust compared with the crumb (Cauvain,

8 1998). Finally, some of the desired flavours and aromas of bread, among

9 which 2-Acetyl-1-pyrroline, 4-hydroxy-2,5-dimethyl-3(2H)-furanone, 2,3-

10 butanedione, methional, (E)-2-nonenal, methylpropanal, and 2- and 3-

11 methylbutanal for baguette crust, are also produced, mainly by the Maillard

12 reaction (Zehentbauer \& Grosch, 1998a; b; Poinot, Arvisenet, Grua-Priol,

13 Colas, Fillonneau, Le Bail et al., 2008).

14 Low water activity (optimal between 0.4 and 0.8) (Charissou, Ait-Ameur \&

15 Birlouez-Aragon, 2007) and high temperatures (commonly above $105^{\circ} \mathrm{C}$ as

16 mentioned above) accelerated the Maillard reaction. WL and browning

17 were linearly correlated (Wahlby et al., 2002; Purlis \& Salvadori, 2007).

18 Independently of the HT mode (natural or forced convection), the lightness

19 of the bread surface decreased as the oven temperature increased (180 to

$20220^{\circ} \mathrm{C}$ ); at even oven air temperatures, forced convection caused higher

21 browning than natural convection (Purlis et al., 2007).

22 Different models based on first order kinetics were proposed to predict the

23 kinetics of colour development. They were dependent on surface

24 temperature alone (Zanoni et al., 1995a) or combined to water content,

25 yielding errors of prediction less than $10 \%$ for WL higher than $10 \%$ (Purlis 
1 et al., 2007) or between 1-24\% on biscuits at the end of baking (Broyart et

2 al., 1998).

3 The Maillard reaction may also result in toxic compounds, such as

4 acrylamide. Several recent reviews have been focalized in the study of

5 acrylamide formation in cereal products (Sadd \& Hamlet, 2005; Konings,

6 Ashby, Hamlet \& Thompson, 2007; Claus, Carle \& Schieber, 2008) (for

7 further details see the cited reviews).

8 Previous studies correlated its formation to the oven air temperature,

9 although the key variable is the exact local temperature at the dough

10 surface which depends on many variables other than the oven air

11 temperature. The amount of acrylamide in the crust of bread, flat bread, dry

12 starch system and dried rye-based flat bread rose with longer baking times

13 and higher oven temperatures (Brathen \& Knutsen, 2005). A similar effect

14 was reported by Ahrne et al. (2007).

\section{$16 \quad 2.4 \quad$ Rheological evolution}

17 The rheological properties of dough change significantly during baking,

18 mainly as the result of the temperature-induced changes to the molecular

19 structures. Between 26 and $60^{\circ} \mathrm{C}$, the viscosity of dough decreased by a

20 factor of 5 (Bloksma, 1990), supporting the deformation of dough films.

21 The water content is a key factor since a variation of $4 \%$ induced a

22 variation in viscosity by a factor of 2 (Bloksma, 1990). Above $60^{\circ} \mathrm{C}$,

23 viscosity increased by a factor of 10 , and the starch granules inflated and

24 the gluten molecules were polymerized, damaging dough extensibility

25 (Bloksma, 1990). Moreover, the higher the heating rate, the lower the 
1 minimum viscosity and the higher the temperature where this minimum

2 viscosity occurred (Bloksma, 1980).

3 Although starch gelatinisation and protein denaturation are responsible for

4 the loss of extensibility of the crumb, this should not apply to the crust

5 (section 2.3.1): starch gelatinisation is expected to be delayed by the high

6 heating rate and the low water content encountered in the crust and this

7 would favour low levels of viscosity. It is thus most probable that the loss

8 of extensibility of superficial layers during baking is due to dehydration,

9 although this point is not clear in the literature.

10 The rheological properties of bread dough have been widely characterised

11 experimentally but generally not in conditions realistically representing the

12 baking process, especially regarding the crust. Firstly, viscosity and

13 eventually elasticity have been thoroughly measured at ambient and/or

14 constant temperatures, but rarely during dynamic heating. When applied,

15 heating rates have been appropriate to the bread core (Collar, Bollain \&

16 Rosell, 2007), and rarely to the crust, the highest comparable values being 9

17 to $11^{\circ} \mathrm{C} / \mathrm{min}$ (Bloksma, 1980; Singh \& Bhattacharya, 2005). Secondly,

18 bread dough has been characterised at very low uniaxial shear rates

19 (between $10^{-2}$ and $10^{-3} \mathrm{~s}^{-1}$ ) (Bloksma, 1990) and more recently under

20 biaxial extension at rates of $5 \times 10^{-2} \mathrm{~s}^{-1}$ (Rouille, Della Valle, Lefebvre,

21 Sliwinski \& vanVliet, 2005) and $10^{-1} \mathrm{~s}^{-1}$ (Dobraszczyk et al., 2008). Most

22 of these strain rates failed to reproduce those encountered during baking (1

23 to $\left.2 \times 10^{-3} \mathrm{~s}^{-1}\right)$ (Bloksma, 1990). With the exception of biaxial extension

24 (Dobraszczyk \& Morgenstern, 2003), other tests used in combination with

25 dynamic heating only approximately reproduce the expected deformation 
1 of dough films over a gas bubble during baking. Finally, rheological

2 measurements applicable to the crust should ideally be conducted under

3 dynamic drying; again most of the data available were obtained at a

4 constant water content, with levels relevant to the dough.

5 In the current mathematical models of baking, the mechanics are usually

6 simplified and the dough considered as viscous only (Lostie et al., 2002b;

7 Lucas et al., 2009) . Viscosity was not dependent on water content and was

8 at best temperature-dependent. Nevertheless, fair agreement between

9 simulation and experiment was usually obtained due to the numerous

10 parameters to be adjusted and because the validation was based on overall

11 measurement of the oven-rise (Lostie et al., 2002a; Zhang et al., 2006), and

12 rarely on local measurements (Lucas et al., 2009). The simplified

13 rheological behaviour of dough (viscous rather than viscoelastic) used in

14 these models could be responsible for the discrepancies in total height

15 (Lostie et al., 2002a) or in the intensity of local compression in the crumb

16 (Lucas et al., 2009).

$18 \quad 2.5$ Cell growth

19 Because of the proximity of the boundary with the oven air, gases easily

20 escape the crust and the pressure remains close to the atmospheric pressure

21 (see pressure profiles calculated by Zhang et al. (2006) and Lucas et al.

22 (2009)). Additionally, the loss of extensibility of dough films is expected to

23 be more rapid, presumably because of the great reduction in water content.

24 Thus, one reason to explain the smaller size of cells in the crust than in the

25 crumb ( 
1 Figure 3) is that the forces favouring expansion are not sufficient for cell

2 growth, although the full mechanism underlying cell growth warrants in

3 depth study.

4 Moreover, the surface layers cannot deform fast enough to accommodate

5 the core expansion. This leads to a domed shaped top surface, and also to

6 similar curvature of the internal structures, i.e. elliptical shapes of cells

7 observed during baking (Whitworth \& Alava, 2004). In fact, when setting

8 of the surface layers occurred early compared to the heating at core (

9 Figure 4f), two opposite forces were exerted on the intermediate regions,

10 which tended to be compressed (

11 Figure 4d), the extent of compression being related to the time elapsed

12 between stiffening of dough films and their rupture (Jefferson, Lacey \&

13 Sadd, 2006; Lucas et al., 2009).

14 The dimension, shape and number of gas cells in the crumb have been

15 studied by various imaging techniques; comparatively the crust was subject

16 of few studies (Datta, Sahin, Sumnu \& Keskin, 2006; Zhang et al., 2006;

17 Primo-Martin et al., 2007). It must be emphasized that the majority of

18 microscopy techniques are destructive and do not allow dynamic

19 observation of a process such as baking. Other techniques providing

20 dynamic measurements often average the bubble size distribution over the

21 whole dough sample, which is relevant in the case of a quite homogeneous

22 alveolar structure as expected during proving (Leroy, Fan, Strybulevych,

23 Belido, Page \& Scanlon, 2008). Another requirement for imaging is high

24 spatial resolution, given that the mean cell size in the crust is around

$25100 \mu \mathrm{m}$. Among the techniques available, X-ray synchrotron seems to be 
1 the most appropriate. A quantitative, dynamic study of the alveolar

2 structure in the crumb during baking was recently reported (Babin, Della

3 Valle, Chiron, Cloetens, Hoszowska, Pernot et al., 2006). The feasibility

4 for the crust still needs to be tested. It would require warming the sample at

5 higher rates and using higher frequencies of acquisition than those used for

6 the crumb, although the signal to noise ratio would be lower due to low

7 water content and low levels of signal accumulation.

93 How the crust affects other mechanisms during baking

$10 \quad 3.1$ Mechanical constraint to crumb expansion, both locally and $11 \quad$ overall

\section{$12 \quad 3.1 .1 \quad$ Loss of extensibility}

13 The cessation of overall expansion was experimentally related to the

14 occurrence of a dry surface during sponge cake (Lostie et al., 2002b) and

15 bread (Zanoni et al., 1993) baking. Similarly, protecting dough samples

16 with paraffin oil to prevent dehydration allowed continuous expansion until

$17 \quad 100^{\circ} \mathrm{C}$, whereas it ceased between 36 and $62^{\circ} \mathrm{C}$ (Le Meste et al., 1992).

18 Using magnetic resonance imaging (MRI) Wagner, Quellec, Trystram \&

19 Lucas (2008a) recently reported that if the crust was set early, and even if

20 total expansion had ceased, local expansion could continue (

21 Figure 4a- c), especially in the colder areas which had not already expanded 22

23 Figure 4f). These areas expanded to the detriment of others which were 24 then compressed ( 
1 Figure 4d). Such compression was accompanied by the disappearance of

2 the largest bubbles, suggesting that it involved the weakest structures from

3 a mechanical view-point. (Zhang, Lucas, Doursat, Flick \& Wagner, 2007)

4 developed a device with a fabric lid which made it possible to stop the

5 oven-rise at different heights. Using MRI they showed that the later the

6 oven-rise was stopped, the deeper the location of the squeezed crumb. Such

7 a trend could be reproduced with a model of baking (

8 Figure 4a-c) which in turn made it possible to relate the occurrence of

9 compression to the mechanical properties of dough films (already ruptured

10 but not already stiffened). Similarly, in the theoretical approach developed

11 by Jefferson et al. (2006), the more a cell is set when its film fractured, the

12 less squashing took place and the lower the final density in that part of the

13 bread. Likewise, Hayman (1998) suggested that crust formation resulted in

14 an increase in the internal pressure in the unbaked portion of the dough,

15 imposing additional stress on the dough films, and ultimately leading to

16 bubble coalescence and to a coarser crumb structure. If no crust was

17 formed, a fine crumb structure was expected, which was evidenced from

18 cross sections of loaves produced with their electrical resistance oven

19 (ERO) for a wide range of wheat flours.

20 Additionally, MRI and X-ray images showed how crust rupture allowed

21 prolongation of the local expansion and also contributed to strong spatial

22 heterogeneity in crumb expansion (Whitworth et al., 2004; Wagner et al., $232008 a)$.

24 Crust setting has rarely been taken into account in the models of baking. To

25 do so, the rheological properties of dough should be dependent on both 
1 temperature and water content (section 2.4). Moreover, a proper description

2 would be two-dimensional (Zhang et al., 2006). In current models of

3 unidirectional transport and expansion, the cessation of oven-rise was

4 "successfully" reproduced by artificially imposing nil displacement of the

5 outer boundary after a certain baking time -adjusted on experimental data

6 e.g. (Lucas et al., 2009), or by using high values of viscosity at high

7 temperatures e.g. (Lostie et al., 2002a).

\section{$8 \quad 3.1 .2 \quad$ Lower permeability to gases}

9 The constraints to crumb expansion may also be generated by low

10 permeability of the crust to gases, through the pressure build-up. Almost no

11 pressure build-up was obtained from baking models when high

12 permeability values with uniform distribution through the dough were used

13 (Zhang et al., 2006). The authors finally retained in their simulations lower

14 permeability for the "crust" (the region of interest was not defined) than for

15 the crumb. The effect of low permeability of the surface layers on the

16 pressure build-up was recently evidenced by Grenier, Le Ray \& Lucas 17 (2009).

18 It is well known that the permeability of a porous medium is affected by the

19 pore fraction and structure. Very little information is available in the 20 literature for the dough/crumb, and some of it is controversial. Baker 21 (1939) related the gas flow to cell size in commercial white bread, but no 22 permeability values are available in this study. Dough permeability was

23 directly related to porosity, whatever the water $(15-50 \% \mathrm{wb})$ and fat $(2-8 \%)$ 24 contents (Goedeken, 1993). Based on this study, the permeability of typical 25 crumb (75\% of porosity) was estimated at around $2.2 \times 10^{-11} \mathrm{~m}^{2}$, and of 
1 typical crust ( $40 \%$ of porosity) around $10^{-12} \mathrm{~m}^{2}$. These orders of magnitude

2 were used for crumb $\left(10^{-11} \mathrm{~m}^{2}\right)$ and crust $\left(2.5 \times 10^{-12} \mathrm{~m}^{2}\right)$ in the baking

3 model developed by Zhang et al. (2006). All other baking models

4 considered uniform permeability through the product (Lostie et al., 2002a;

5 Lucas et al., 2009), which makes their simulations of $\mathrm{CO}_{2}$ release and 6 oven-rise questionable.

$7 \quad 3.1 .3 \quad$ Secondary effect on the gas released (through pressure build-up)

9 Zhang et al. (2007) monitored the $\mathrm{CO}_{2}$ released during baking and 10 observed an induction period followed by a sudden, linear increase in $\mathrm{CO}_{2}$

11 release, ending with a plateau zone. They also found that the earlier the 12 oven-rise was stopped, the shorter the induction period. Similar trends 13 could be reproduced by a mathematical model of baking, which showed in 14 addition that film rupture was necessary but not sufficient to demonstrate $15 \mathrm{CO}_{2}$ release and that it must be accompanied by a pressure build-up similar 16 to that stemming from an early cessation of the oven-rise. Similarly, Lucas, 17 Le Ray, Peu, Wagner \& Picard (2007) found lower $\mathrm{CO}_{2}$ release for lower 18 oven air temperatures, which delayed the formation of the crust.

$19 \mathrm{CO}_{2}$ was considered to be the main gas responsible for oven-rise (Bloksma, 20 1990). Leakage of $\mathrm{CO}_{2}$ obviously implies a decreasing amount of gas in 21 cells and presumably a lower potential for cell growth. Interpreting the $\mathrm{CO}_{2}$ 22 release is however a little more complicated since it also reveals a build-up 23 in internal pressure, which is the driving force for cell growth provided that 24 the dough films are still deformable. The net balance between these two 25 antagonistic mechanisms has not been assessed to date. $\mathrm{CO}_{2}$ is also 
1 regarded as a vector of transport of the aromatic compounds (Eliasson et

2 al., 1993). For all these reasons, the mechanisms governing $\mathrm{CO}_{2}$ release

3 warrant further investigation for a thorough understanding and a clear

4 identification of the key factors.

\section{$5 \quad 3.2 \quad$ A barrier to heat and water transport}

6 Wahlby et al. (2002) compared the WL of buns reheated with and without

7 crust. Whatever the heating time, WL without crust was three times greater

8 than with crust. This was attributed to the differences in crust and crumb

9 porosity. Breads baked in an impingement or hybrid oven (forced

10 convection combined with microwave) lose less water than conventionally

11 baked breads (Patel, Waniska \& Seetharaman, 2005). This was attributed to

12 early crust formation in the former case. Although this effect on WL is

13 commonly accepted (Eliasson et al., 1993), the underlying mechanisms

14 have only recently been studied with the aid of models (Lostie et al., 2004;

15 Zhang et al., 2008).

16 As reported in section 2.2, HT governed the progress of the vaporisation

17 front in the surface layers and thus WL during baking. As the front went

18 deeper, the resistance to HT increased and slowed down the WL. Similarly,

19 high porosity in the surface layers increased this resistance (Vanin, Grenier,

20 Doursat, Flick, Trystram \& Lucas, 2009) since the same amount of water

21 was distributed over a thicker area. Changes in thermal conductivity could

22 also affect the resistance to HT in the surface layers and in turn the WL

23 (Vanin et al., 2009). Thermal conductivity of the dough/crumb decreased

24 with decreasing water content and increasing porosity (Rask, 1989; Zanoni,

25 Peri \& Gianotti, 1995b; Jury et al., 2007). However, conductivity measured 
1 on crust and crumb samples has been found to be very close (Jury et al.,

2 2007), meaning that the effects of porosity and water content may

3 compensate for each other.

4 Water transport to the core by the evaporation-condensation-diffusion

5 mechanism also contributed to the dehydration of superficial layers, but to

6 a lower extent; it was theoretically favoured by higher porosity in the

7 crumb (Zhang et al., 2008).

8 It must be remembered here that the porosity profile which affects the crust

9 thickening through the mechanisms described above is itself greatly

10 affected by fairly early setting of the crust (see section 3.1.1, and also

11 Figure 4a-c). A thorough understanding of these strongly interlinked

12 mechanisms is necessary for fine control of crust formation, WL and local

13 density together (Vanin et al., 2009).

\section{Conclusion}

\section{4.1 Can a definition of the “crust" region be proposed?}

17 An accurate definition of the spatial domain comprising the crust remains

18 necessary for any further study. Changes in its properties are believed to be

19 gradual, making it difficult to define a boundary with the crumb beneath.

20 A crust is commonly referred to as a dry, hard, dense, coloured zone,

21 following exposure to high temperatures: “... a hard, vitreous surface layer

22 formed of collapsed crumb pore walls” (Eliasson et al., 1993); “.... denser,

23 darker surface parts bread, near to its surface" (Jefferson et al., 2006). It

24 must be remembered that low water content and high temperature are 
1 determinants (but not the only) of many of the other features (colour,

2 porosity, molecular structures, hardness...).

3 Only a few experimental studies gave their criterion separating the crust

4 from the crumb. The crust sample was often unique, distinguishable from

5 the crumb sample(s) by its darker colour (visual criterion, e.g. (Lind et al.,

6 1991)) or its more cohesive, harder structure (mechanical property e.g.

7 (Westerlund et al., 1989)). Many factors, including lower water content,

8 higher density, smaller and more elongated cells, vitreous transition, etc...

9 may contribute together or separately to a distinct mechanical behaviour.

10 Mechanical separation may also originate from constraints created during

11 cooling e.g. (Le Bail, Monteau, Lucas, Chargelègue \& Reverdy, 2005) in

12 the case of part-baked breads. (Zanoni et al., 1993) separated the crust by

13 quick freezing which caused rupture between the "crust" and "crumb". All

14 this makes the mechanical criterion not very reliable when comparing

15 results from various studies. The same applies to colour, with the effect of

16 small carbohydrates.

17 Surprisingly, despite these raw criteria, the properties measured on crust

18 samples are quite consistent between studies (

19 Figure 1). Likewise, thickness of the crust has been reported to increase

20 linearly with baking time (Zanoni et al., 1993; Wiggins, 1998). However,

21 the number of studies is not sufficient to conclude at this stage.

22 From a theoretical point-of-view, the crust boundary can be refined by

23 using a threshold value applied to a criterion such as density or water

24 content. Jefferson et al. (2006) characterised crust thickness as the distance

25 from the surface where the final density was the same as the original dough 
1 density and Zhang et al. (2008) from the top surface to the point where the

2 water flowed most rapidly, i.e. the vaporisation front. A criterion with

3 physical relevance to the threshold should represent a sharp change

4 between the surface and the core, as water content or temperature do (

$5 \quad$ Figure 4e, f). Porosity presents either no sharp change (

$6 \quad$ Figure 4a) or many sharp changes (

7 Figure 4c) between the surface and core, which makes this criterion hardly

8 reliable. Corresponding experimental profiles of water content and

9 temperature are few and thus it is a definition that could not be applied at

10 the experimental level to date. All this supports the need to develop a non-

11 invasive, dynamic technique to study the specific behaviour of surface

12 layers, with the special requirement of high spatial resolution.

\section{$13 \quad 4.2$ Need for further research}

14 Superficial bread layers differ from core layers of the crumb mainly in their

15 dynamics during baking. Lack of published data and information on

16 prevailing mechanisms in the superficial layers of bread have prevented

17 modelling studies from considering crust setting and its effects on heat,

18 mass transport and cell growth in the crumb, as well as the full

19 understanding and control of baking.

20 On the one hand, this review has shown that the knowledge acquired

21 regarding the crumb cannot be extrapolated to superficial layers with

22 confidence, especially because the mechanisms are highly interrelated,

23 often working antagonistically and because they are highly sensitive to

24 temperature and water content. The identification of prevailing mechanisms

25 thus remains an issue for future studies. 
1 On the other hand, we have attempted to fill the gap in the published data

2 through the different enclosed charts. We have also shown that methods of

3 measurement for monitoring the dynamics (temperature, water content) in

4 the superficial layers present limitations in terms of convenience and

5 accuracy, and there is a real need to develop, or sometimes simply

6 implement, non-intrusive, continuous techniques of measurement. The

7 dynamics impact on the microstructures and hence the main properties of

8 the crust. Understanding of the underlying reactions has been inferred from

9 measurements performed on samples of different water content, but very

10 few studies have related heating to drying. There is therefore a real

11 challenge to reproduce these dynamics with miniaturisation inside the

12 instrument of analysis (rheometer or X-ray synchrotron for instance).

13 Aguilera (2005) recently emphasized the possibilities offered by the recent

14 advances in imaging to dynamically study of microstructures during

15 processing. All these developments will contribute to providing

16 information of higher spatial resolution and to a clearer definition of the

17 crust region, a prerequisite for further studies in this area.

\section{Acknowledgments}

19 This study was carried out with financial support from the Council of

20 Brittany (France) and the European Community Commission (FP6,

21 Thematic Area "Food quality and safety", FOOD-2006-36302 EU-

22 FRESHBAKE). It does not necessarily reflect the Commission's views and

23 in no way anticipates the Commission's future policy in this area. 


\section{References}

Ahrne, L., Andersson, C.G., Floberg, P., Rosen, J., \& Lingnert, H. (2007). Effect of crust temperature and water content on acrylamide formation during baking of white bread: Steam and falling temperature baking. Lwt-Food Science and Technology, 40(10), 1708-1715.

Attenburrow, G.E., Goodband, R.M., Taylor, L.J., \& Lillford, P.J. (1989). Structure, mechanics and texture of a food sponge. Journal of Cereal Science, 9(1), 61-70.

Babin, P., Della Valle, G., Chiron, H., Cloetens, P., Hoszowska, J., Pernot, P., Reguerre, A.L., Salvo, L., \& Dendievel, R. (2006). Fast X-ray tomography analysis of bubble growth and foam setting during breadmaking. Journal of Cereal Science, 43(3), 393-397.

Baik, O.D., Marcotte, M., \& Castaigne, F. (2000). Cake baking in tunnel type multi-zone industrial ovens - Part I. Characterization of baking conditions. Food Research International, 33(7), 587-598.

Baker, J.C. (1939). The permeability of bread by air. Cereal Chemistry, 16, 730.

Bassal, A., Vasseur, J., \& Lebert, A. (1993). Measurement of wacter activity above $100{ }^{\circ}$ C. Journal of Food Science, 58(2), 449-452.

Biliaderis, C.G., Maurice, T.J., \& Vose, J.R. (1980). Starch gelatinisation phenomena studied by differential scanning calorimetry. Journal of Food Science, 45, 1669-1674.

Bloksma, A.H. (1980). Effect of heating rate on viscosity of wheat flour doughs. Journal of Texture Studies, 10(3), 261-269.

Bloksma, A.H. (1990). Rheology of the breadmaking process. Cereal Foods World, 35(2), 228-236 and 959-960. 
1 Brathen, E., \& Knutsen, S.H. (2005). Effect of temperature and time on the formation of acrylamide in starch-based and cereal model systems, flat breads and bread. Food Chemistry, 92(4), 693-700.

Broyart, B., Trystram, G., \& Duquenoy, A. (1998). Predicting colour kinetics during cracker baking. Journal of Food Engineering, 35(3), 351-368.

6 Burt, D.J., \& Russell, P.L. (1983). Gelatinization of low water content wheat

Cauvain, S.P. (1998). Bread - The product. in S.P. Cauvain, L.S. Young (Eds.), Technology of Breadmaking (pp. 1-17). London, UK: Blackie Academic

12 Champenois, Y., Colonna, P., Buléon, A., Valle, G.D., \& Renault, A. (1995).

Charissou, A., Ait-Ameur, L., \& Birlouez-Aragon, I. (2007). Kinetics of formation Starch gelatinisation and gelation in white pan bread. Sciences des Aliments, 15, 593-614. of three indicators of the maillard reaction in model cookies: Influence of baking temperature and type of sugar. Journal of Agricultural and Food Chemistry, 55(11), 4532-4539.

Chevallier, S., Colonna, P., \& Lourdin, D. (2000). Contribution of major ingredients during baking of biscuit dough systems. Journal of Cereal Science, 31(3), 241-252.

Claus, A., Carle, R., \& Schieber, A. (2008). Acrylamide in cereal products: A review. Journal of Cereal Science, 47(2), 118-133.

Collar, C., Bollain, C., \& Rosell, C.M. (2007). Rheological behaviour of formulated bread doughs during mixing and heating. Food Science and Technology International, 13(2), 99-107. 
1 Cuq, B., Abecassis, J., \& Guilbert, S. (2003). State diagrams to help describe wheat bread processing. International Journal of Food Science and Technology, 38(7), 759-766.

4 Czuchajowska, Z., Pomeranz, Y., \& Jeffers, H.C. (1989). Water activity and

6 Datta, A.K., Sahin, S., Sumnu, G., \& Keskin, S.O. (2006). Porous media

Dobraszczyk, B.J., \& Morgenstern, M.P. (2003). Rheology and the breakmaking process. Journal of Cereal Science, 38, 229-245.

11 Dobraszczyk, B.J., \& Salmanowicz, B.P. (2008). Comparison of predictions of baking volume using large deformation rheological properties. Journal of Cereal Science, 47(2), 292-301.

Donovan, J.W. (1979). Phase transitions of the starch-water system. Bio-polymers, $18,263-275$.

Dogan, I.S. (2002). Dynamic rheological properties of dough as affected by amylases from various sources. Nahrung-Food, 46(6), 399-403.

Eliasson, A.C. (1980). Effect of water content on the gelatinization of wheat starch. Starch/ Starke, 32(8), 270-272.

Eliasson, A.C., \& Larsson, K. (1993). Cereals in Breadmaking. A molecular colloidal approach. New York: Marcel Dekker Inc.

Fan, J., Mitchell, J.R., \& Blanshard, J.M.V. (1999). A model for the oven rise of dough during baking. Journal of Food Engineering, 41, 69-77.

24 Fessas, D., \& Schiraldi, A. (2000). Starch gelatinization kinetics in bread dough DSC investigations on 'simulated' baking processes. Journal of Thermal Analysis and Calorimetry, 61(2), 411-423. 
Glatzel, H., \& Rettenmaier, G. (1962). Nutritional comparaison of bread products. IV. Postprandial hyperglycemia. Nutr Dieta Eur Rev Nutr Diet, 4, 283-96 (in German).

Goedeken, D.L. (1993). Permeability measurements of porous food materials. Journal of Food Science, 58(6), 1329-1331.

6 Grenier, D., Le Ray, D., \& Lucas, T. (2009). Combined local pressure-temperature

Huang, V.T., Haynes, L., Levine, H., \& Slade, L. (1996). Glass transitions measurements during bread making: Insight on the crust properties and alveolar structure. submitted to. Journal of Cereal Science. instarch, gluten and bread as measured dieletrectric spectroscopy and TMA methods. Journal of Thermal Analysis, 47, 1289-1298.

Jefferson, D.R., Lacey, A.A., \& Sadd, P.A. (2006). Understanding crust formation during baking. Journal of Food Engineering, 75(4), 515-521.

Jenkins, P.J., \& Donald, A.M. (1998). Gelatinisation of starch: a combined SAXS/WAXS/DSC and SANS study. Carbohydrate Research, (308), 133-147.

Jury, V., Monteau, J.Y., Comiti, J., \& Le-Bail, A. (2007). Determination and prediction of thermal conductivity of frozen part baked bread during thawing and baking. Food Research International, 40(7), 874-882.

Konings, E.J.M., Ashby, P., Hamlet, C.G., \& Thompson, G.A.K. (2007). Acrylamide in cereal and cereal products: A review on progress in level reduction. Food Additives and Contaminants, 24, 47-59.

Le Bail, A., Monteau, J.Y., Lucas, T., Chargelègue, A., \& Reverdy, Y. (2005). Impact of selected process parameters on crust flaking of frozen partbaked bread. Journal of Food Engineering, 69(4), 503-509.

Le Meste, M., Huang, V.T., Panama, J., Anderson, G., \& Lentz, R. (1992). GlassTransition of Bread. Cereal Foods World, 37(3), 264-267. 
1 Leroy, V., Fan, Y., Strybulevych, A.L., Belido, G.C., Page, J.H., \& Scanlon, M.G. (2008). Investigating the Bublle Size Distribution in Dough Using Ultrasound. in G.M. Campbell, M.G. Scanlon, D.L. Pyle (Eds.), Bubbles in Food 2 (pp. 51-60). St Paul: Eagan Press.

Lind, I., \& Rask, C. (1991). Sorption isotherms of mixed minced meat, dough and bread crust. Journal of Food Engineering, 14, 303-315.

Lostie, M., Peczalski, R., Andrieu, J., \& Laurent, M. (2002a). Study of sponge cake batter baking process. II: Modeling and parameter estimation. Journal of Food Engineering, 55(4), 349-357.

Lostie, M., Peczalski, R., Andrieu, J., \& Laurent, M. (2002b). Study of sponge cake batter baking process. I: experimental data. Journal of Food Engineering, 51(2), 131-137.

Lostie, M., Peczalski, R., \& Andrieu, J. (2004). Lumped model for sponge cake baking during the "crust and crumb" period. Journal of Food Engineering, 65(2), 281-286.

Lucas, T., Le Ray, D., Peu, P., Wagner, M., \& Picard, S. (2007). A new method for continuous assessment of $\mathrm{CO} 2$ released from dough baked in ventilated ovens. Journal of Food Engineering, 81(1), 1-11.

Lucas, T., Wagner, M., Doursat, C., Flick, D., \& Trystram, G. (2009). Heat and mass transport and expansion during bread baking. II. Simulation and experimental verification. submitted to. AIChE Journal.

Luyten, A., Pluter, J.J., \& van Vliet, T. (2004). Crispy/crunchy crusts of cellular solid foods: A literature review with discussion. Journal of Texture Studies, 35(5), 445-492.

Marston, P.E., \& Wannan, T.L. (1976). Bread baking: the transformation from dough to bread. The Bakers Digest, 1976(august), 24-28. 
1 Martins, S.I.F.S., Jongen, W.M.F., \& van Boekel, M.A.J.S. (2001). A review of Maillard reaction in food and implications to kinetic modelling Trends in Food Science \& Technology, 11, 364-373.

Mondal, A., \& Datta, A.K. (2008). Bread baking - A review. Journal of Food Engineering, 86(4), 465-474.

Myers, C.D. (1990). Study of thermodynamics and kinetics of protein stability by thermal analysis. in V.R. Harwalkar, C.Y. Ma (Eds.), Thermal Analysis of Food (pp. 16-50). USA: Elsevier science publishers LTD.

9 Noel, T.R., Parker, R., Ring, S.G., \& Tatham, A.S. (1995). The glass-transition behavior of wheat gluten proteins. International Journal of Biological Macromolecules, 17(2), 81-85.

O'Brien, J., \& Morrissey, P.A. (1989). Nutritional and Toxicological Aspects of the Maillard Browning Reaction in Foods. Critical Reviews in Food Science and Nutrition, 28(3), 211-248.

Patel, B.K., Waniska, R.D., \& Seetharaman, K. (2005). Impact of different baking processes on bread firmness and starch properties in breadcrumb. Journal of Cereal Science, 42(2), 173-184.

Patel, B.K., \& Seetharaman, K. (2006). Effect of heating rate on starch granule morphology and size. Carbohydrate Polymers, 65(3), 381-385.

Poinot, P., Arvisenet, G., Grua-Priol, J., Colas, D., Fillonneau, C., Le Bail, A., \& Prost, C. (2008). Influence of formulation and process on the aromatic profile and physical characteristics of bread. Journal of Cereal Science, 48(3), 686-697.

Primo-Martin, C., van Nieuwenhuijzen, N.H., Hamer, R.J., \& van Vliet, T. (2007). Crystallinity changes in wheat starch during the bread-making process: Starch crystallinity in the bread crust. Journal of Cereal Science, 45(2), 219-226. 
1 Purlis, E., \& Salvadori, V.O. (2007). Bread browning kinetics during baking. Journal of Food Engineering, 80(4), 1107-1115.

Rask, C. (1989). Thermal properties of dough and bakery products : a review of published data. Journal of Food Engineering, 9, 167-193.

Rouille, J., Della Valle, G., Lefebvre, J., Sliwinski, E., \& vanVliet, T. (2005).

Sadd, P., \& Hamlet, C. (2005). The formation of acrylamide in UK cereal Shear and extensional properties of bread doughs affected by their minor components. Journal of Cereal Science, 42(1), 45-57. products. Chemistry and Safety of Acrylamide in Food, 561, 415-429.

Singh, A.P., \& Bhattacharya, M. (2005). Development of dynamic modulus and cell opening of dough during baking. Journal of Texture Studies, 36(1), 44-67.

Stokes, D.J., \& Donald, A.M. (2000). In situ mechanical testing of dry and hydrated breadcrumb in the environmental scanning electron microscope (ESEM). Journal of Materials Science, 35(3), 599-607.

Strecker, T.D., Cavalieri, R.P., Zollars, R.L., \& Pomeranz, Y. (1995). Polymerization and Mechanical Degradation Kinetics of Gluten and Glutenin at Extruder Melt-Section Temperatures and Shear Rates. Journal of Food Science, 60(3), 532-\&.

Thorvaldsson, K., \& Skjöldebrand, C. (1996). Method and instrument for measuring local water content inside food. Journal of Food Engineering, $29,1-11$.

Thorvaldsson, K., \& Skjöldebrand, C. (1998). Water Diffusion in Bread During Baking. Lebensmittel Wissenschaft und Technologie, 31, 658-663.

Van Nieuwenhuijzen, N.H., Tromp, R.H., Hamer, R.J., \& Van Vliet, T. (2007). Oscillatory water sorption test for determining water uptake behavior in bread crust. Journal of Agricultural and Food Chemistry, 55(7), 26112618. 
1 Vanin, F.M., Grenier, D., Doursat, C., Flick, D., Trystram, G., \& Lucas, T. (2009). Water loss and crust formation during bread baking. II. Technological insights from a sensitivity analysis. submitted to. Journal of Food Engineering.

Wagner, M., Quellec, S., Trystram, G., \& Lucas, T. (2008a). MRI evaluation of local expansion in bread crumb during baking. Journal of Cereal Science, 48(1), 213-223.

Wagner, M.J., Lucas, T., Le Ray, D., \& Trystram, G. (2007). Water transport in bread during baking. Journal of Food Engineering, 78(4), 1167-1173.

Wagner, M.J., Loubat, M., Sommier, A., Le Ray, D., Collewet, G., Broyart, B., Quintard, H., Davenel, A., Trystram, G., \& Lucas, T. (2008b). MRI study of bread baking: experimental device and MRI signal analysis. International Journal of Food Science and Technology, 43(6), 1129-1139.

Wahlby, U., \& Skjoldebrand, C. (2002). Reheating characteristics of crust formed on buns, and crust formation. Journal of Food Engineering, 53(2), 177184.

Wang, X., Choi, S.G., \& Kerr, W.L. (2004). Effect of gluten content on recrystallisation kinetics and water mobility in wheat starch gels. Journal of the Science of Food and Agriculture, 84(4), 371-379.

Westerlund, E., Theander, O., \& Aman, P. (1989). Effects of baking on protein and aqueous ethanol-extractable carboydrate in white bread fractions. Journal of Cereal Science, 10, 139-147.

Whitworth, M.B., \& Alava, J.M. (2004). Non-destructuve imaging of bread and cake structure during baking. In 12th ICC Cereal \& Bread Congress, Harrogate (UK),

Wiggins, C. (1998). Proving, baking and cooling. in S.P. Cauvain, L.S. Young (Eds.), Technology of Breadmaking (pp. 120-148). London: Blackie Academic \& Professional. 
1 Zanoni, B., \& Peri, C. (1993). A study of the bread-baking process. I: A phenomenological model. Journal of Food Engineering, 19(4), 389-398.

Zanoni, B., Peri, C., \& Bruno, D. (1995a). Modelling of of browning kinetics of bread crust during baking. Lebensmittel Wissenschaft \& Technologie, 28(6), 604-609.

6 Zanoni, B., Peri, C., \& Gianotti, R. (1995b). Determination of the thermal diffusivity of bread as a function of porosity. Journal of Food Engineering, 26(4), 497-510.

9 Zehentbauer, G., \& Grosch, W. (1998a). Crust aroma of baguettes - I. Key odorants of baguettes prepared in two different ways. Journal of Cereal Science, 28(1), 81-92.

Zehentbauer, G., \& Grosch, W. (1998b). Crust aroma of baguettes II. Dependence of the concentrations of key odorants on yeast level and dough processing.

Zhang, J., \& Datta, A.K. (2006). Mathematical modeling of bread baking process. Journal of Food Engineering, 75(1), 78-89.

17 Zhang, L., Lucas, T., Doursat, C., Flick, D., \& Wagner, M. (2007). Effects of crust

\section{Table and figure list}

26 Figure 1: Water content in crust (hollow symbols) and crumb (filled 27 symbols) during baking from different literature sources. 
2 Figure 2: Dependence on water content of gelatinisation temperatures of

3 wheat starch-water mixtures and GT of gluten and bread as demonstrated

4 by DSC from different literature sources.

6 Figure 3: Microstructure of bread baked in microwave-infrared

7 combination oven observed by SEM at $\times 50$ for (a) crumb, (b) crust. Bars

8 represent $300 \mu \mathrm{m}$. Source: Datta et al. (2006).Reprinted from Journal of

9 Food Engineering, 79, Datta, A.K., Sahin, S., Sumnu, G., \& Keskin, S.O.,

10 Porous media characterisation of breads baked using novel heating modes.

11 106-116, Copyright (2006), with permission from Elsevier.

13 Figure 4: Porosity profile for different final total heights (45(a), 50(b) and $1455(\mathrm{c}) \mathrm{mm}$ ) after $45 \mathrm{~min}$ of baking. Porosity (d), water content (e) and 15 temperature (f) profiles at different baking times for a final height of 60 16 mm. Adapted from Zhang et al. (2007) and Lucas et al. (2009).

17

18 Table 1: Heating rates for different cereal products and baking conditions at 19 bread surface and core.

20

21 
Table 1

\begin{tabular}{|c|c|c|c|c|c|c|}
\hline Product & $\begin{array}{c}\text { Mass of } \\
\text { dough/ } \\
\text { batter } \\
\text { (g) }\end{array}$ & $\begin{array}{c}\text { Surfaces } \\
\text { exposed to } \\
\text { heat transfer }\end{array}$ & $\begin{array}{c}\text { Position of } \\
\text { temperature } \\
\text { in dough/ } \\
\text { batter }\end{array}$ & $\begin{array}{c}\text { Oven air } \\
\text { temperature } \\
\left(\mathrm{C}^{\circ}\right)\end{array}$ & $\begin{array}{l}\text { Heating rate } \\
\qquad\left({ }^{\circ} \mathrm{C} / \mathrm{min}\right)\end{array}$ & Reference \\
\hline Bread & 200 & top bottom & $\begin{array}{c}\text { top surface } \\
\text { bottom surface } \\
\text { centre }\end{array}$ & 185 & $\begin{array}{l}7.7 \\
2.6 \\
2.4\end{array}$ & $\begin{array}{l}\text { (Wagner et } \\
\text { al., 2008) }\end{array}$ \\
\hline Bread & 341 & all & $\begin{array}{l}\text { top surface } \\
\text { bottom surface } \\
\text { at } 1 \mathrm{~cm} \text { beneath } \\
\text { the top surface }\end{array}$ & 203 & $\begin{array}{l}11.3 \\
9.5 \\
2.6\end{array}$ & $\begin{array}{l}\text { (Zanoni et } \\
\text { al., 1993) }\end{array}$ \\
\hline Bread & - & all & $\begin{array}{l}\text { top surface } \\
\text { mid-width } \\
\text { centre }\end{array}$ & 210 & $\begin{array}{l}10.3^{*} \\
3.9^{*} \\
1.8^{*}\end{array}$ & $\begin{array}{c}\text { (Thorvaldss } \\
\text { on et al., } \\
\text { 1996) }\end{array}$ \\
\hline $\begin{array}{l}\text { Pan bread } \\
\text { Francala }\end{array}$ & - & - & surface & 220 & $\begin{array}{c}8.8 \\
14.4 \\
\end{array}$ & $\begin{array}{l}\text { (Dogan, } \\
\text { 2002) }\end{array}$ \\
\hline Bread & $1.5 \mathrm{~L}$ & all & $\begin{array}{l}\text { top surface } \\
\text { bottom surface }\end{array}$ & 225 & 6.7 & $\begin{array}{c}\text { (Thorvaldss } \\
\text { on et al., } \\
\text { 1998) }\end{array}$ \\
\hline Bread & 760 & all & $\begin{array}{c}\text { side surface } \\
\text { centre }\end{array}$ & 235 & $\begin{array}{l}7.4 \\
2.8\end{array}$ & $\begin{array}{c}\text { (Marston et } \\
\text { al., 1976) }\end{array}$ \\
\hline Biscuit & - & all & centre & 300 & $\begin{array}{c}75.0^{* *} \\
(400 \mathrm{~g} / \mathrm{kg} \text { dry air) }\end{array}$ & (Chevallier \\
\hline
\end{tabular}


300

61.7 $\quad$ et al., 2002)

(20g/kg dry air)

240

$44.7^{* *}$

(200g/kg dry air)

$19.6^{* *}$

180

(20g/kg dry air)

$\begin{array}{lllllll}\text { Sponge cake } 400-600 & \text { top surface } & 200 & 0.5 & \text { (Lostie et } \\ & & & & \text { al., 2002b) }\end{array}$

“_“ refers to missing information

* data from reheated samples

${ }^{* *}$ with different relative air humidity 


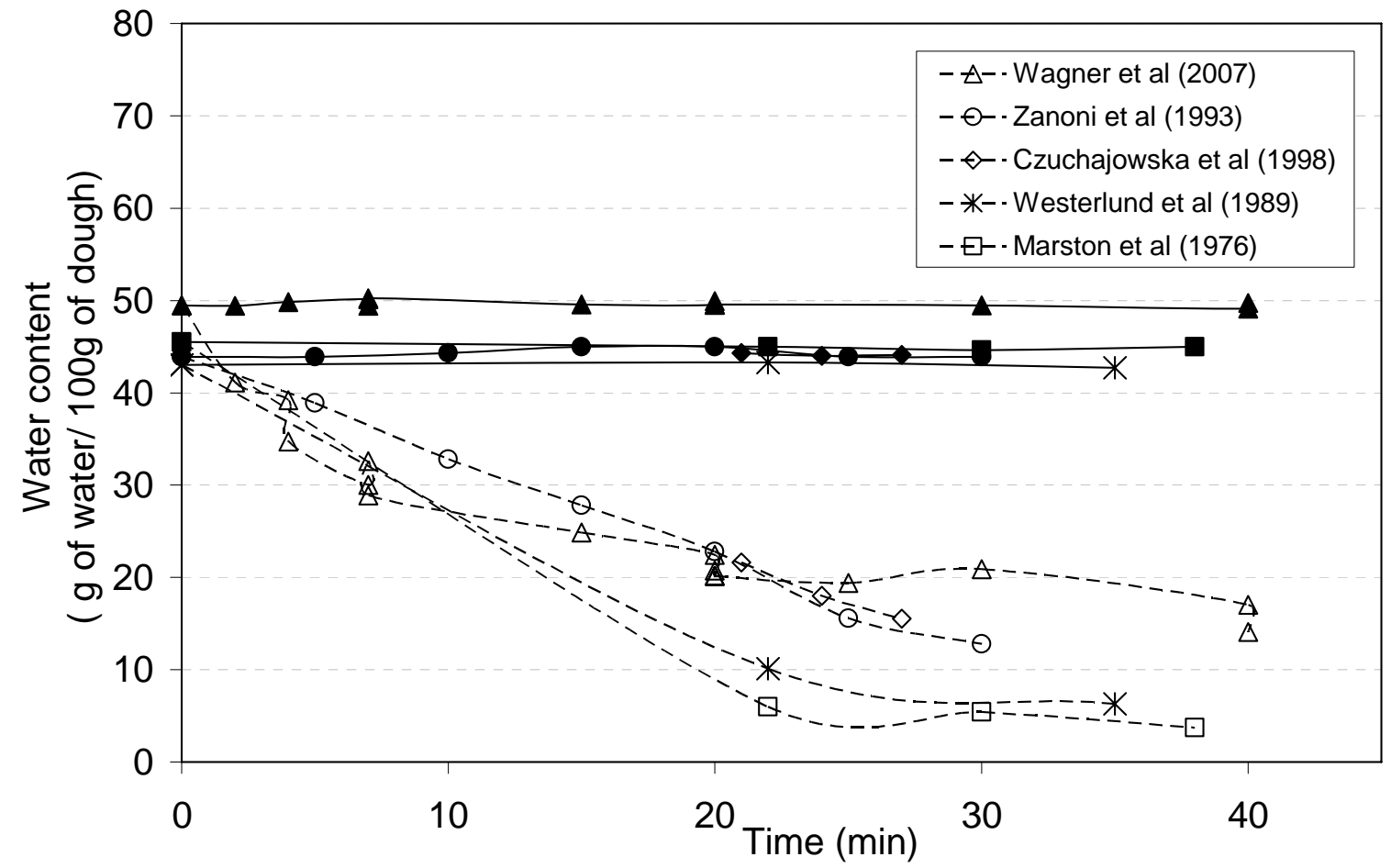

Figure 1 


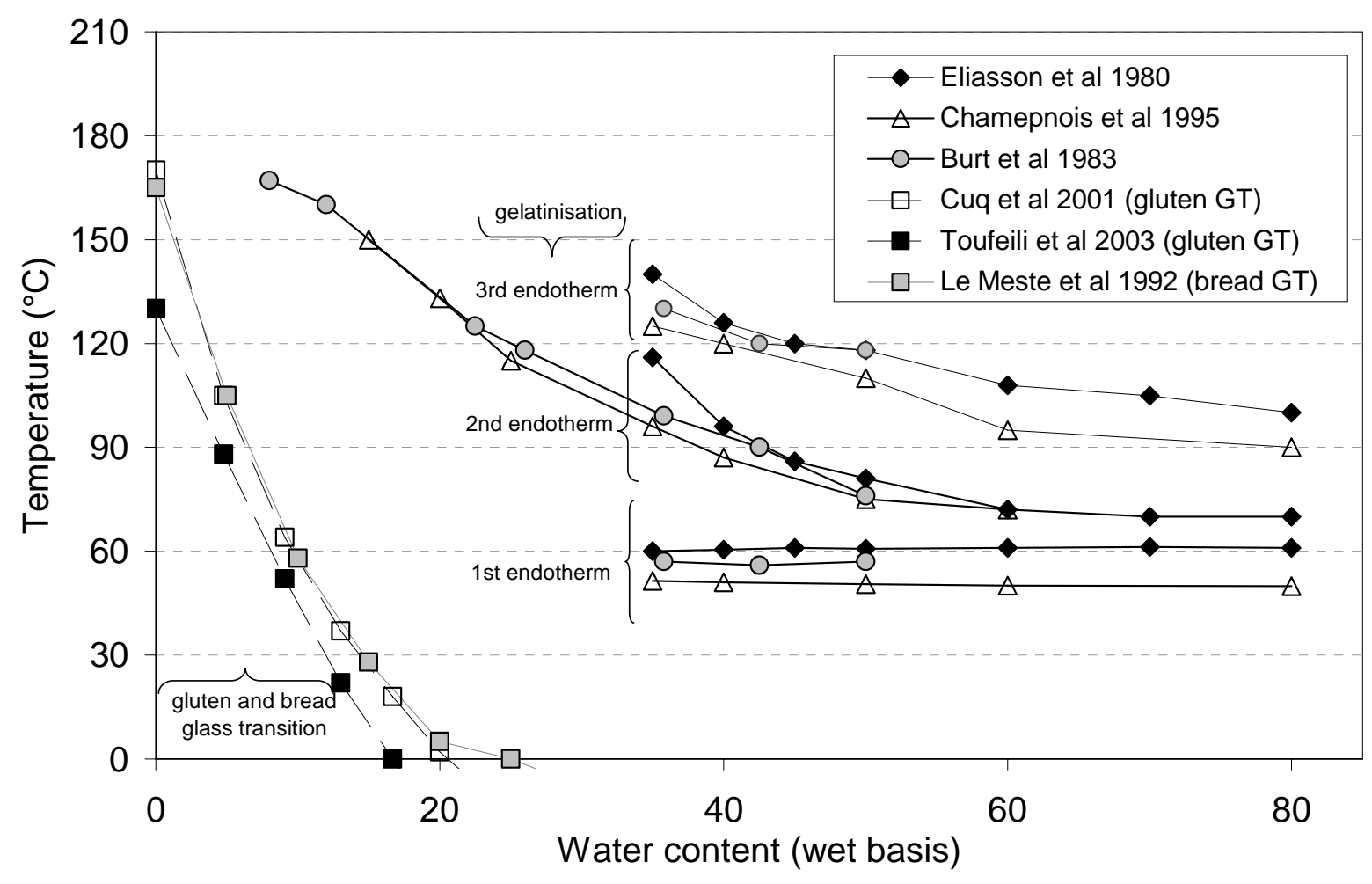

Figure 2 


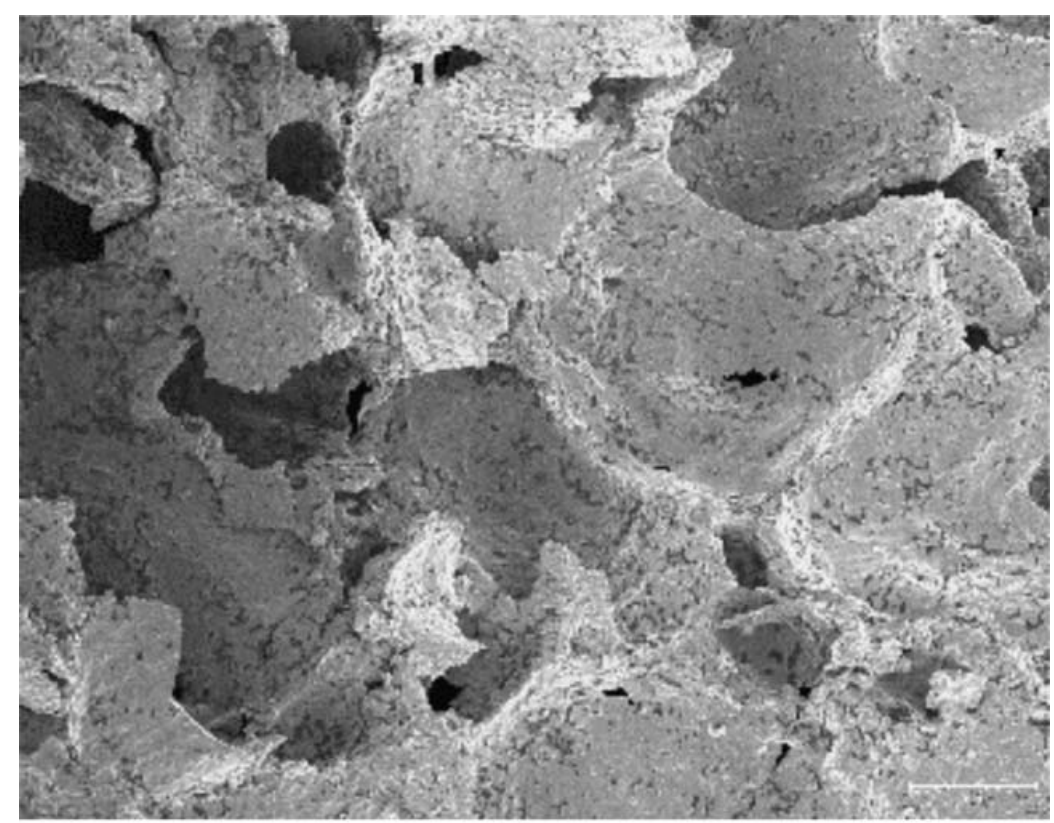

(a)

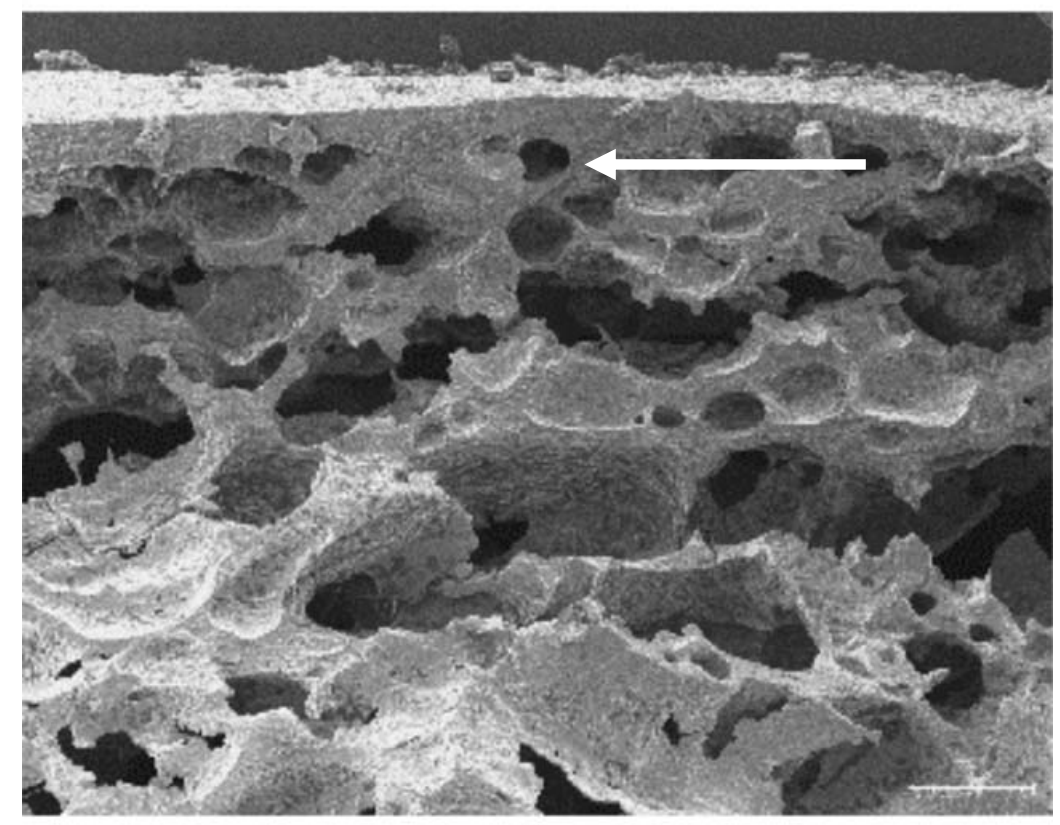

(b)

Figure 3 


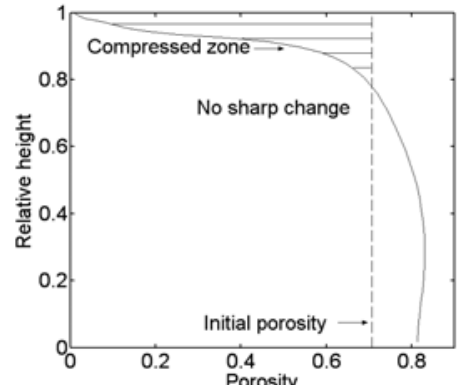

(a)

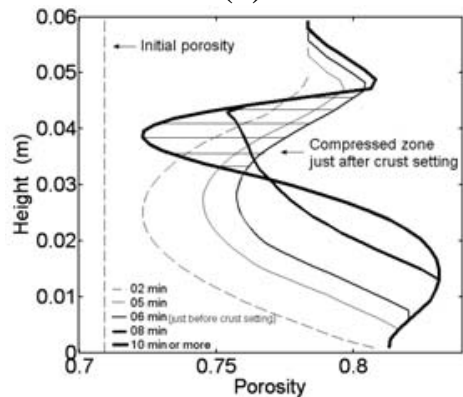

(d)

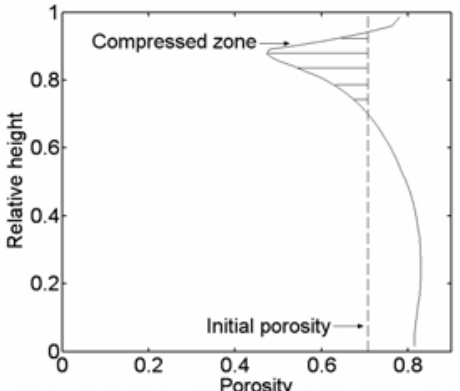

(b)

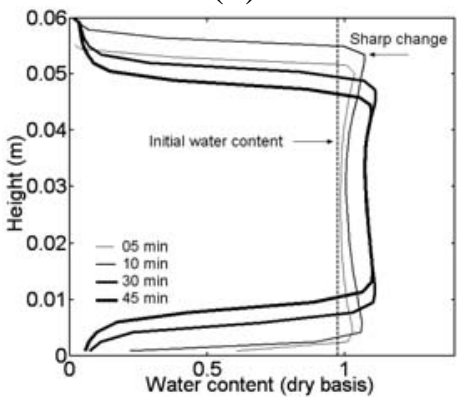

(e)

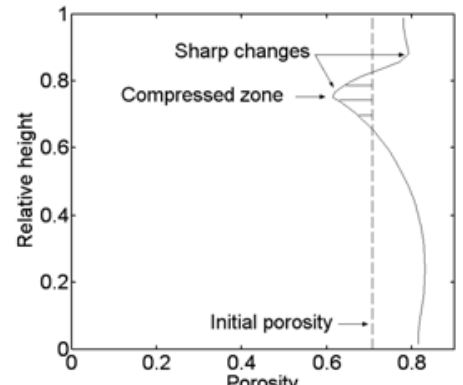

(c)

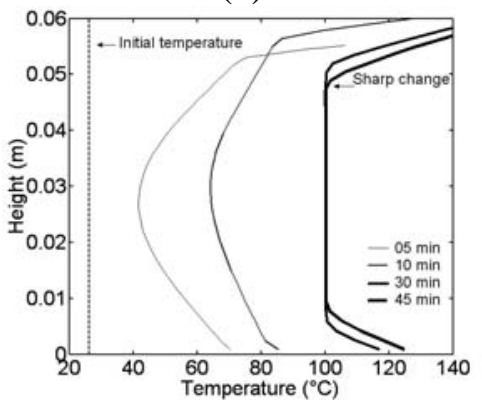

(f)

Figure 4 